Scientific journal

\section{PHYSICAL AND MATHEMATICAL EDUCATION}

Has been issued since 2013.

Науковий журнал

ФІЗИКО-МАТЕМАТИЧНА ОСВІТА

Видається з 2013.
ISSN 2413-158X (online)

ISSN 2413-1571 (print)

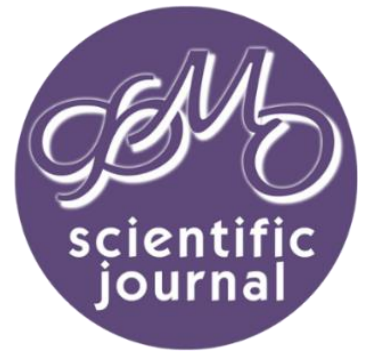

\title{
http://fmo-journal.fizmatsspu.sumy.ua/
}

Татауров В.П., Шишкіна М.П. Використання сервісів Microsoft Office 365 у процесі навчання дисципліни «Інформаційні технології в освіті» у закладі вищої педагогічної освіти. Фізико-математична освіта. 2019. Випуск 4(22). С. 124-129.

Tataurov V., Shyshkina M. Use of Microsoft Office 365 services in the process of learning information technologies in education in higher education pedagogical institution. Physical and Mathematical Education. 2019. Issue 4(22). P. 124-129.

DOI 10.31110/2413-1571-2019-022-4-019
Удк 378.091.31:004.9

В.П. Татауров

Кам'янець-Подільський національний університет імені Івана Огієнка, Україна viktor.tataurov@kpnu.edu.ua ORCID: 0000-0001-9490-8981

М.П. Шишкіна

Інститут Інформаційних технологій і засобівнав навчання НАПнУкраїни, Україно shyshkina@iitlt.gov.ua

ORCID:0000-0001-5569-2700

ВИКОРИСТАННЯ CEPВICIB MICROSOFT OFFICE 365

У ПРОЦЕСІ НАВЧАННЯ ДИСЦИПЛІНИ «ІНФОРМАЦІЙНІ ТЕХНОЛОГІЇ В ОСВІТІ» У ЗАКЛАДІ ВИЩОЇ ПЕДАГОГІЧНОЇ ОСВІТИ

\begin{abstract}
АНОТАЦІЯ
У роботі охарактеризовано схему, основні підходи до проектування хмаро орієнтованого середовища навчання інформаційних технологій в освіті на базі Оffice 365 , наведено результати експериментального дослідження.

Формулювання проблеми. Необхідність дослідження обумовлена потребою підвищення ІКТ компетентності студентів, вчителів, працівників закладів педагогічної освіти, поліпшення їх обізнаності з методиками і досвідом використання програмного забезпечення, що постачається «у хмарі».

Матеріали і методи. Для досягнення мети роботи були використані загальнонаукові методи: а) теоретичні - аналіз психологопедагогічної літератури з проблеми дослідження; узагальнення вітчизняного і зарубіжного досвіду; теоретичний аналіз, систематизація та узагальнення наукових фактів і закономірностей б) емпіричні - анкетування; опитування; бесіди з учасниками освітньо-наукового середовища; педагогічні спостереження за начальною і науковою діяльністю суб'єктів освітнього процесу, педагогічний експеримент. Експериментальна база дослідження: Кам'янець-Подільський національний університет імені Івана Огієнка, в експерименті взяли участь магістри фізичних, математичних, педагогічних спеціальностей закладу вищої педагогічної освіти, об'єм вибірки - 160 чоловік.

Результати. У роботі обгрунтовано, що завдяки методично виваженому запровадженню у процес навчання дисципліни «Інформаційні технології в освіті» сервісів Microsoft Office 365 у закладі вищої педагогічної освіти відбувається статистично значуще покращення результатів навчання студентів (статистично обгрунтовано згідно критерію Колмогорова-Смирнова).

Висновки. Педагогічний експеримент підтвердив гіпотезу дослідження, що методично обгрунтоване запровадження розробленої методики використання сервісів Microsoft Office 365 сприятиме активізації навчальної діяльності і покращенню ії результатів.
\end{abstract}

КлючОвІ СлОВА: хмарні сервіси, методика, спільна робота, освітнє середовище, заклад вищої освіти.

ВСТУП

Постановка проблеми. Модернізація і розвиток процесу підготовки кадрів належать до актуальних проблем реформування сучасної освіти. У зв'язку із запровадженням хмарних сервісів і технологій у цей процес формуються нові напрями науково-педагогічних досліджень, пов'язані з поданням електронних ресурсів і сервісів, уможливленням колективної роботи з програмними додатками, зняттям географічних або часових обмежень набування освіти та інші. Саме завдяки використанню хмарних сервісів виникають можливості вирішення нагальних соціальних та освітньокультурних проблем сучасного суспільства, серед яких, зокрема, - підвищення рівня доступності і якості освіти, удосконалення освітньо-наукового середовища підготовки кадрів, ширше запровадження в освітній процес найсучасніших IKT.

Сучасний стан розвитку освітньо-наукового середовища (ОНС) характеризується підвищенням вимог до якості електронних ресурсів наукового та навчального призначення, поширенням більш гнучких, персоніфікованих, відкритих організаційних систем, що стає можливим із використанням сервісів хмарних інформаційно-комунікаційних платформ. 
Постає проблема створення методик використання сервісів хмарних технологій у процесі підготовки кадрів для сфери освіти, особливо у процесі навчання дисциплін, пов'язаних з опануванням основ використання IКТ в освіті. Адже саме це $\epsilon$ необхідною передумовою підготовки фахівця, здатного до успішного і ефективного застосування найсучасніших IKT у своїй професійній діяльності.

Сервіси Microsoft Office 365 як комплексного універсального засобу, що поєднує у собі різноманітні типи інструментів, можуть виявитися найбільш перспективними з точки зору запровадження середовища навчання на єдиній основі, що не потребує в той же час розгортання хмаро орієнтованої ІКТ інфраструктури у закладі освіти силами IT підрозділів самого закладу, це здійснюватиметься на боці провайдера. В той же час, набір сервісів, що постачається у цьому пакеті програм, є достатньо потужним і функціональним для того, щоб забезпечити опанування основ інформаційних технологій студентами педагогічних спеціальностей на сучасному рівні, тобто він містить засоби роботи з офісними додатками, надання простору для зберігання даних, комунікації, колективної і індивідуальної роботи, створення груп, проектування сайтів, опрацювання даних та багато іншого.

Постає проблема проектування методики використання сервісів Microsoft Office 365 у процесі опанування основ інформаційно-комунікаційних технологій в освіті студентами педагогічних спеціальностей.

Актуальність роботи обумовлена необхідністю підвищення ефективності і результативності впровадження в освітній процес закладів вищої педагогічної освіти інформаційно-комунікаційних технологій хмарних обчислень, що визнані провідними засобами IKT у сучасному Європейському освітньому просторі, поліпшення показників їх використання, покращення рівня підготовки кадрів. Використання у закладах вищої педагогічної освіти засобів і сервісів хмаро орієнтованого середовища є суттєвою передумовою підготовки ІКТ-компетентних фахівців, здатних до подальшого активного, доцільного, науково обґрунтованого застосування хмарних технологій у своїй професійній педагогічній діяльності.

Аналіз актуальних досліджень. Результати останніх досліджень (Вакалюк, 2016; Литвинова, 2016; Arpaci, 2017) свідчать, що використання хмарних сервісів в освітньому процесі закладів вищої освіти $є$ актуальним предметом досліджень. Розглядаються такі питання, як організація спільного доступу до програмного забезпечення навчального призначення; створення і використання електронних освітніх ресурсів, підтримування процесів відкритого навчання і досліджень; командної роботи та ін. (Носенко\&Попель\&Шишкіна, 2015). Зокрема у роботах С.Г. Литвинової розглядаються різні аспекти формування і використання хмаро орієнтованого навчального середовища закладу освіти на базі Microsoft Office 365 (Литвинова, 2016). Використання даного сервісу у закладі вищої педагогічної світи $є$ актуальним предметом досліджень, бо цей засіб дозволяє створити досить багатофункціональне і комплексне середовище без необхідності його розгортання на боці користувача (за моделлю «програмне забезпечення як сервіс», SaаS). В той же час, сервіси Microsoft Office 365 постійно вдосконалюються, розширюючи спектр інструментів підтримування освітнього процесу. Зокрема, малодослідженим питанням залишається використання сервісів спільної роботи, зокрема, Microsoft Teams у закладі вищої педагогічної освіти. Особливий інтерес у цьому плані має процес навчання дисципліни «Інформаційно-комунікаційні технології в освіті», бо саме в цій дисципліні мають закладатися основи ІКТ-компетентності фахівців, здатних до впровадження і використання у своїй професійній діяльності інноваційних педагогічних технологій, зокрема, спільної роботи у хмаро орієнтованих середовищах.

Мета статті. Метою статті є: відобразити сучасні підходи до проектування процесу навчання дисципліни «Інформаційно-комунікаційні технології в освіті» у закладі вищої педагогічної освіти і охарактеризувати досвід навчання цієї дисципліни із використанням хмарних сервісів Microsoft Office 365.

\section{МЕТОДИ ДОСЛІДЖЕННЯ}

Для досягнення мети роботи були використані загальнонаукові методи: а) теоретичні - аналіз психологопедагогічної літератури з проблеми дослідження для з'ясування стану розробленості питання використання хмарних сервісів Microsoft Office 365 у процесі навчання дисципліни «Інформаційно-комунікаційні технології в освіті» у закладі вищої педагогічної освіти; узагальнення вітчизняного і зарубіжного досвіду застосування хмарних сервісів і технологій у закладах вищої освіти для визначення кращих зразків використання хмаро орієнтованих IKT і шляхів їх використання у процесі навчання; теоретичний аналіз, систематизація та узагальнення наукових фактів і закономірностей для розроблення і проектування моделей використання хмарних сервісів у процесі підготовки кадрів у закладі педагогічної освіти, обґрунтування основних висновків; б) емпіричні - анкетування; опитування; бесіди з учасниками освітньонаукового середовища; педагогічні спостереження за начальною і науковою діяльністю суб'єктів освітнього процесу, педагогічний експеримент - для визначення рівня сформованості ІКТ-компетентності учасників освітнього процесу; в) статистичні - перевірка статистичних гіпотез для аналізу та інтерпретації результатів дослідження.

\section{РЕЗУЛЬТАТИ ДОСЛІДЖЕННЯ}

Сучасні підходи до організації освітнього процесу передбачають використання принципово нових форм, що потребує змін складу і структури навчального середовища, функцій педагогічних систем, спрямованих на активізацію навчально-пізнавальної діяльності його учасників.

Метою створення хмаро орієнтованого навчального середовища у закладах освіти $є$ розширення доступу до якісних електронних ресурсів і сервісів для усіх його учасників, підвищення рівня їх IKT-компетентності, забезпечення можливості навчання у будь-якому місті і у будь-який час. Одним з різновидів хмаро орієнтованого середовища $\epsilon$ навчальна хмара, розгорнута на основі сервісів Microsoft Office 365.

Для того, щоб запровадити хмарні сервіси в освітній процес, необхідно провести спеціальне навчання, розробивши відповідні його елементи, зокрема, внести зміни до змісту підготовки, перепідготовки, підвищення кваліфікації викладацького персоналу та провести предметне навчання студентів. Зміст навчання має бути спрямований на розвиток IКT компетентності науково-педагогічних кадрів, працівників ІТ-підрозділів, що забезпечують освітній процес, а також студентів щодо використання різноманітних видів хмарних сервісів у процесі навчання дисциплін. 
Зміст навчання згідно пропонованої методики охоплює предметне навчання сервісів Microsoft Office 365 для проектування освітнього середовища студента і викладача, забезпечення доступу до засобів і сервісів навчального призначення, відпрацювання технологій використання електронних освітніх ресурсів і оцінювання результатів навчання; а також використання сервісів Microsoft Office 365 для опанування змісту навчання дисципліни згідно визначених змістових ліній: «Проектна діяльність, проект, навчальний проект», «Обробка і оформлення великих документів», Створення та використання освітніх веб-ресурсів (Wiki)», «Інформаційно-освітні середовища, як системи управління освітнім процесом і засоби постачання освітнього контенту», "Хмарні технології для інформатизації освіти. Використання Web-технологій в освітньому процесі», «Розробка електронних освітніх ресурсів та сценаріїв навчальних занять 3 використанням засобів інформатизації освіти», «Технології педагогічного проектування цифрового освітнього ресурсу», «Модульна контрольна робота».

Методами навчання, що застосовуються згідно зазначеної методики, є: словесні (лекції, пояснення, бесіди); практичні (лабораторні та практичні роботи, вправи, розв'язання задач); дослідницькі (частково-пошуковий; проблемнопошуковий; евристичний).

Формами навчання є: лекції, семінари, вебінари, веб-конференції, індивідуальні консультації тощо.

Методика використання MS Office 365 була запроваджена в освітній процес на фізико-математичному факультеті Кам'янець-Подільського національного університету імені Івана Огієнка. MS Office 365 використовувався для надання спільного доступу до навчальних матеріалів студентам і викладачам, забезпечення умов для колективної роботи. Було використано безкоштовний план, що був доступний для працівників закладу освіти та студентів. Учасники освітнього процесу мали зареєструватися у хмаро орієнтованому середовищі, отримати акаунт, завдяки якому вони мали доступ до низки сервісів як для індивідуального, так і колективного використання. Зокрема, застосовувалися офісні сервіси (MS Word, MS PowerPoint, MS Excel, а також електронний записник OneNote), також учасникам надавався доступ до соціальної мережі Yammer, необмеженого обсягу пам'яті в хмарному сховищі для кожного користувача, а також інструментарію для створення сайтів SharePoint. За умов використання хмарних сервісів дані зберігаються у центрі обробки даних, а не на локальному комп'ютері користувача, тоді як доступ до них забезпечується через браузер, $\epsilon$ можливим з різних пристроїв, з яких можна вийти в Інтернет. За хмарної моделі організації доступу до ІКТ виникають необхідні умови для формування навичок командної роботи, які потрібні сучасному фахівцеві, що має бути обізнаним 3 використанням IT (рис. 1).

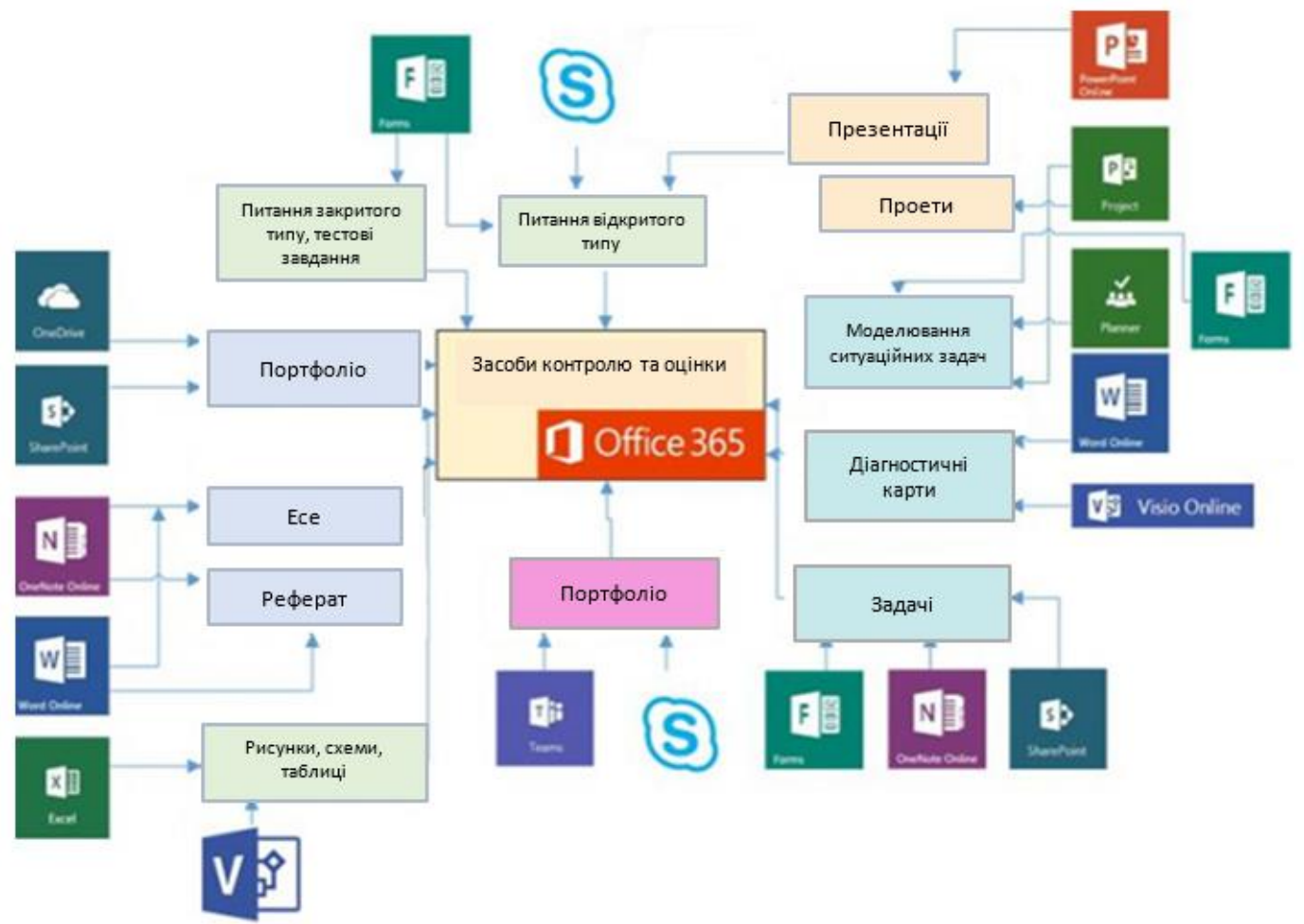

Рис. 1. Структура навчальної хмари на базі MS Office 365

Для початку роботи у хмаро орієнтованому середовищі необхідно було налаштувати електронну пошту Outlook. Маючи адресу е-пошти, користувач може отримувати доступ до усіх інших сервісів Microsoft Office 365. Електронна пошта застосовувалася для обміну повідомленнями, як засіб спілкування. Для розміщення навчальних матеріалів використовувалося сховище даних OneDrive, для розміщення навчальних завдань, отримання результатів, оцінювання студентських робіт, надання методичних вказівок використовувався електронний записник OneNote. Організація роботи у хмаро орієнтованому середовищі здійснювалася за допомогою інструментарію підтримування спільної роботи MS Teams.

Microsoft Teams містить набір інструментів для створення проектної команди для роботи в групі (у ній мають бути зареєстровані студенти і викладачі); управління контентом у додатках у межах єдиного робочого простору. Студенти і викладачі мають можливість отримувати своєчасну інформацію через засоби командних бесід, приватних чатів, зборів 
проектних груп та ін. При цьому в процесі спільної роботи можна прозоро використовувати додатки Microsoft Office 365, a caмe Word, Excel, PowerPoint, записник OneNote для опрацювання навчальних матеріалів і проведення занять (Татауров, Чевська, 2018). У процесі роботи викладач може створювати такі матеріали, як файли Microsoft Office; бібліотеки сайтів SharePoint Office 365; навчальні відео матеріали (YouTube, Microsoft Stream); ресурси OneNote (для організації занять); файли і бібліотеки файлів у OneDrive; анкети, тести (Microsoft Forms) та інші.

Методику використання сервісів Microsoft Office 365 як засобу навчання основ використання інформаційних технологій в освіті студентів закладів вищої педагогічної освіти визначено як теоретично обґрунтовану систему мети, змісту, методів, засобів, форм використання сервісів Microsoft Office 365 у навчанні даної дисципліни. Суб'єктами методики є студенти спеціальності 013 „Початкова освіта” педагогічного факультету, та спеціальностей 014.04 Середня освіта (Математика) та 011 „Освітні, педагогічні науки” фізико-математичного факультету та викладачі дисципліни «Інформаційні технології в освітньому процесі» і «Інформаційно-комунікаційні технології в освіті і науці» об'єктами сервіси Microsoft Office 365 і електронні ресурси навчання даної дисципліни.

3 метою експериментальної перевірки ефективності розробленої методики у 2013 - 2018 рр. було проведено педагогічний експеримент. Для проведення педагогічного експерименту було сформовано експериментальні і контрольні групи. До експериментальної групи потрапили 118 студентів, магістрів освітніх програм «Початкова освіта» педагогічного факультету, "Математика», «Інформатика» фізико-математичному факультеті Кам'янець-Подільського національного університету імені Івана Огієнка; до контрольної групи - 42 студенти освітньої програми «Освітні вимірювання» фізикоматематичного факультету цього ж університету.

Для перевірки ефективності розробленої методики навчання було виконано порівняння навчальних досягнень студентів за рівнями підготовки за традиційною методикою та розробленою.

В ході експерименту було забезпечено дотримання всіх вимог щодо застосування статистичних методів опрацювання результатів дослідження: випадковий характер вибірок; однорідність та незалежність вибірок;.

В результаті формувального етапу експерименту було побудовано гістограму порівняльного розподілу навчальних досягнень студентів за результатами підсумкового екзамену з дисципліни «Інформаційно-комунікаційні технології в освіті». Було отримано результати, що свідчили про підвищення загальних показників успішності з дисципліни в експериментальних групах - кількість студентів, які мали низьку кількість балів (1-39), знизилася з 15,09\% до 8,36 \%; кількість тих, які мали середню кількість балів (40-74), знизилася з 56,34 до 43,61; кількість тих, які мали достатню кількість балів (75-89), підвищилася з 22,23\% до 40,21\%; кількість тих, які мали високу кількість балів, (90-100), підвищилася з 6,34\% до 8,83\%. Перевірку отриманих під час формувального експерименту вибірок було проведено за $\lambda$-критерієм Колмогорова-Смирнова. Емпіричне значення критерію $\lambda_{\text {eмn }}=4,27$, тоді як табличне значення цього критерію $\lambda_{k p}(0,05)=1,36$ для рівня значущості $\alpha=0,05$, Емпіричне значення перевищує табличне, таким чином, з імовірністю $95 \%$ можна стверджувати, що існує статистично значуща відмінність між рівнем навчальних досягнень в експериментальній і контрольній групах, зумовлена використанням розробленої методики.

\section{ОБГОВОРЕННЯ}

Проведене дослідження свідчить, що засобами MS Office. Зокрема, MS Teams, можна організувати роботу в групі таким чином, що вона стає більш активною і ефективною, про що свідчить покращення результатів навчання студентів, зокрема, зростання частки студентів з середнім і високим рівнем успішності з дисципліни. Виникає більше можливостей для студента взяти участь у дискусії, звернутися зі своїми питаннями до викладача або до інших членів групи, активно залучитися до виконання завдань. Він має персоніфікований доступ до навчальних ресурсів, а також може брати участь у колективній роботі з ними, в залежності від тих цілей, які будуть поставлені.

Завдяки використанню хмарних технологій можна сформувати поліфункціональне навчальне середовище на єдиній основі, завдяки чому вдається досягти активізації освітнього процесу, формувати у студентів навички колективної роботи над навчальними проектами, модерувати спільну роботу студентів та викладачів, ефективно опрацьовувати значні обсяги даних і відомостей, раціонально організовувати час і наявні ресурси. Всі ці навички $є$ необхідними для повноцінного існування і самореалізації майбутнього фахівця в інформаційному суспільстві, що ставить перед його членами нові, сучасні вимоги.

\section{ВИСНОВКИ ТА ПЕРСПЕКТИВИ ПОДАЛЬШОГО ДОСЛІДЖЕННЯ}

Аналіз теоретичних досліджень і досвіду навчання основ інформаційних технологій в освіті дав можливість виявити протиріччя між: розширенням асортименту і поліпшенням користувацьких властивостей програмного забезпечення і електронних ресурсів навчального призначення, що постачаються «у хмарі», та недостатнім рівнем сформованості відповідних методик їх використання; потребою поширення в освітньому процесі і загалом у практиці роботи закладів освіти найсучасніших IKT і недостатнім рівнем їх використання; необхідністю підвищення ІКТ компетентності студентів, вчителів, працівників закладів педагогічної освіти і низьким рівнем обізнаності з кращими зразками засобів IKT освітнього призначення, що існують нині.

Аналіз інструментарію Microsoft Office 365, зокрема, OneDrive, OneNote, MicrosoftTeams, групи, календарі та ін. як засобів, що використовуються в процесі створення і використання навчальних матеріалів, комунікації у процесі навчання, організації самостійної роботи студентів, а також навчання у співробітництві, з описом визначальних характеристик таких програмних засобів дозволив визначити переваги саме цих засобів при опанування основ інформаційних технологій в освіті.

Зокрема, серед таких переваг є можливість розміщення навчальних матеріалів "у хмарі», що забезпечує як індивідуалізований, так і колективний доступ до процесу навчання у будь-якому місті і у будь-який час, організації навчальної комунікації зі студентами за допомогою чату, відео-сеансів, електронної пошти, обміну миттєвими повідомленнями; надання і перевірки навчальних завдань; організація колективної роботи за допомогою додатків та ін. 
Сучасні підходи до розвитку освітньо-наукового середовища закладу вищої педагогічної освіти передбачають використання принципово нових форм його організації, спрямованих на модернізацію освітнього процесу, приведення його у відповідність до сучасного рівня розвитку інформаційно-комунікаційних технологій, запитів і потреб здобувача освіти, забезпечення нових форм навчально-пізнавальної діяльності тих, хто вчиться. Для цього потрібно створювати хмаро орієнтовані компоненти освітнього призначення і відповідні методики їх використання, спрямовані на розширення доступу до якісних електронних освітніх ресурсів (EOP) і сервісів у процесі навчання. Актуальним напрямом розвитку ЕОР $€$ застосування хмарних технологій і сервісів Microsoft Office 365 як комплексного універсального засобу, що поєднує у собі різні типи інструментів різного призначення.

Аналіз результатів експериментального випробування запропонованої методики використання сервісів Microsoft Office 365 як засобу навчання основ інформаційних технологій в освіті показав, що рівень навчальних досягнень студентів в експериментальних групах має статистично значущі відмінності у порівнянні з рівнем досягнень студентів в контрольних групах. На підставі цього можна дійти висновку, що зростання рівня було зумовлено саме застосуванням вказаної методики використання хмарних сервісів MS Office 365 для формування компетентностей студентів 3 дисципліни, що i підтверджує гіпотезу дослідження. Перспективою подальших досліджень є розроблення нових компонентів методики або окремих методик використання хмарних сервісів в аспекті формування освітнього середовища закладів педагогічної освіти.

\section{Список використаних джерел}

1. Биков В.Ю. Хмарні технології, ІКТ-аутсорсинг і нові функції ІКТ підрозділів освітніх і наукових установ. Інформаційні технології в освіті, 2011. №10. С.8-23.

2. Вакалюк Т.А. Модель хмаро орієнтованої системи підтримки навчання бакалаврів інформатики. Інформаційні технології і засоби навчання, 2016. № 6 (56). C. 64-76. http://journal.iitta.gov.ua/index.php/itlt/article/view/1415/1098

3. Татауров В.П., Чевська К.С. Використання сервісів для організації освітньо-інформаційного середовища студентів ІTспеціальностей. Збірник наукових праць Кам'янець-Подільського національного університету імені Івана Огієнка. Серія педагогічна, 2018. Вип. 24: С. 120-124.

4. Литвинова С. Г., Спірін О. М., Анікіна Л. П. Хмарні сервіси Office 365. Київ. : Компринт, 2015. 170 с.

5. Литвинова С. Г. Проектування хмаро орієнтованого навчального середовища загальноосвітнього навчального закладу : монографія. Київ. : Компринт, 2016. 354 с.

6. Носенко Ю. Г., Попель М. В., Шишкіна М.П.. Хмарні сервіси і технології у науковій і педагогічній діяльності. Київ, 2016. 79 c. http://lib.iitta.gov.ua/706199/

7. Arpaci Ibrahim. Antecedents and consequences of cloud computing adoption in education to achieve knowledge management. Computers in Human Behavior, 2017. Vol.70. Pp. 382-390.

\section{References}

1. Bykov, V. (2012). Khmarni tekhnolohii, IKT-autsorsynh i novi funktsii IKT pidrozdiliv osvitnikh i naukovykh ustanov [ICT Outsourcing and New Functions of ICT Departments of Educational and Scientific Institutions]. Information Technologies and Learning Tools, 30(4), http://journal.iitta.gov.ua/index.php/itlt/article/view/717 [In Ukrainian].

2. Vakaliuk T. (2016). Model khmaro oriientovanoi systemy pidtrymky navchannia bakalavriv informatyky [The model of the cloud-based system of informatics bachelors learning support]. Information Technologies and Learning Tools, 6 (56), 64-76, http://journal.iitta.gov.ua/index.php/itlt/article/view/1415/1098 [In Ukrainian].

3. Tataurov, V.P., Chevska, K.S. (2018). Vykorystannia servisiv dlia orhanizatsii osvitno-informatsiinoho seredovyshcha studentiv IT-spetsialnostei. [Use of services for organization of educational and information environment of students of IT-specialties]. Collection of scientific works of Kamianets-Podilskyi National University named after Ivan Ogienko. The series is pedagogical, 24, $120-124$ [In Ukrainian].

4. Lytvynova, S. H., Spirin, O. M., Anikina, L. P. (2015). Khmarni servisy Office 365. [Office 365 cloud services]. Kiev. : Comprint [In Ukrainian].

5. Lytvynova S. H. (2016). Proektuvannia khmaro oriientovanoho navchalnoho seredovyshcha zahalnoosvitnoho navchalnoho zakladu [Designing a cloud-oriented educational environment of a comprehensive educational institution]: a monograph. Kyiv: Comprint [In Ukrainian].

6. Nosenko Yu. H., Popel M. V., Shyshkina M.P. (2016). Khmarni servisy i tekhnolohii u naukovii i pedahohichnii diialnosti. [Cloud services and technologies in scientific and pedagogical activity], Kyiv, http://lib.iitta.gov.ua/706199/ [In Ukrainian].

7. Arpaci Ibrahim. (2017). Antecedents and consequences of cloud computing adoption in education to achieve knowledge management. Computers in Human Behavior, 70, 382-390.

\section{USE OF MICROSOFT OFFICE 365 SERVICES IN THE PROCESS OF LEARNING INFORMATION TECHNOLOGIES IN EDUCATION IN HIGHER EDUCATION PEDAGOGICAL INSTITUTION Viktor Tataurov}

Kamianets-Podilskyi National University named after Ivan Ogienko, Ukraine Mariya Shyshkina

Institute of Information Technologies and Learning Tools of NAES of Ukraine

Abstract. The authors highlight Microsoft Office 365 services across a variety of IT support facilities in higher education, as such that can enhance access to e-learning resources, enforce new approaches to education, support data processing, and and introduction of advanced training technologies. The MicrosoftOffice 365 tools are analyzed, including OneDrive, OneNote, MicrosoftTeams, groups, calendars, and more as tools used in the process of creating and using educational materials, communication in the learning process, the organization of independent work of students, as well as training in collaboration. The description of the defining features of such software tools allowed to determine the benefits of these tools in mastering the basics of information technology in education study in institutions of higher pedagogical education. These benefits include the ability to host cloud-based learning materials to provide 
both individual and collective access to the learning process in any place and at any time, organizing educational communication with students via chat, video, sessions, emails, instant messaging; provision and verification of educational tasks; organizing teamwork with applications, etc. The scheme, the basic approaches to designing a cloud-oriented environment of learning information technology in education basing on Office365 are considered, the results of experimental research are presented.

Formulation of the problem. Modern approaches to the development of educational and scientific environment of the institution of higher pedagogical education involve the use of fundamentally new forms of its organization, aimed at modernizing the educational process, bringing it in line with the current level of development of information and communication technologies, requests and needs of the educational provider, cognitive activity of learners. To do this, you need to create cloud-oriented educational components and appropriate techniques for their use, aimed at enhancing access to quality of e-learning resources and services in the learning process. The current trend in the development of the learning resources is the use of cloud technologies and services of Microsoft Office 365 as a comprehensive universal tool that combines different types of instruments for various purposes. Analysis of theoretical studies and experience of learning the basics of information technology in education revealed the contradictions between: expanding the range and improving the usability of software and electronic resources for educational purposes supplied "in the cloud" and the lack of formation of appropriate methods of their use; the need to disseminate in the educational process and in general in the practice of educational institutions the best kinds of modern ICTs and the insufficient level of their use; the need to increase the ICT competences of students, teachers, pedagogical education staff and the low level of awareness of the best examples of ICT educational tools currently available.

Materials and methods. To achieve the goal of the work the research methods were used: a) theoretical - analysis of psychological and pedagogical literature on the problem of research; generalization of domestic and foreign experience; theoretical analysis, systematization and generalization of scientific facts and laws b) empirical - questioning; poll; conversations with participants of educational and scientific environment; pedagogical observations on the initial and scientific activity of the subjects of the educational process, pedagogical experiment. Experimental base of research: Kamyanets-Podilskyi National University named after Ivan Ogienko, masters of physical, mathematical, pedagogical specialties of pedagogical institution of higher education, sample size - 160 people.

Results. It was substantiated that due to scientifically grounded and methodologically sound introduction of services of Microsoft Office 365 into the process of teaching the discipline "Information Technologies in Education" in the institution of higher pedagogical education, there is a statistically significant increase in the level of ICT competence and student performance (statistically consistent).

Conclusions. The pedagogical experiment confirmed the hypothesis of the study that the methodologically justified introduction into the process of teaching the discipline "Information Technologies in Education" in the institution of higher pedagogical education by a specially developed method of using the Microsoft Office 365 services will help to stimulate learning activities and improve learning outcomes.

Keywords: cloud services, methodology, collaboration, educational environment, higher education institution. 